LEGE ARTIS

Language yesterday, today, tomorrow

Vol. II. No 22017

\title{
CONCEPTUALIZATION OF MOTION IN COMMUNICATIVE SPACE IN ENGLISH
}

\section{Svitlana Virotchenko}

Virotchenko, S. (2017). Conceptualization of motion in communicative space in English. In Lege artis. Language yesterday, today, tomorrow. The journal of University of SS Cyril and Methodius in Trnava. Warsaw: De Gruyter Open, 2017, vol. II (2), December 2017, p. 392-444. DOI: 10.1515/lart2017-0020 ISSN 2453-8035

\begin{abstract}
The study of space and motion in space as well as its further verbalization remains one of the topical issues of present-day linguistic research, though motion in personal space still needs a more detailed analysis. This paper analyzes English verbalization of movement in communicative space from a cognitive linguistic perspective. It aims at revealing specific features of the constructions under study by applying such a theoretical tool of cognitive linguistics as image schemas.
\end{abstract}

Keywords: addressee's / addresser's communicative space, image schema, motion in communicative space, verbal constructions of motion in space, verbalization.

\section{Introduction}

The study of space has been of great interest to philosophers and specialists in different spheres of scientific knowledge since ancient times, and it remains a matter of current interest for linguists. Representatives of various schools of thought keep turning to the study of space over and over again: they analyze different approaches to the study of space in different cultures and languages, describe different ways of conceptualizing space relations (Кубрякова 2004; Лебедева 2000; Подлесская 2000; Shaffer \& Leeson 2017), study parameterization of space (Болдырев 2000; Віротченко 2016; Гак 2000; Кобозева 2000; Тошович 2000; Janzen 2017), and spatial metaphors (Булыгина 2000; Мечковская 2004; Alcaraz-Carrión 2017; Radden 1996). The sphere of their research interest also embraces meaningful changes in communicants' personal space resulting from their movement and / or change of position in communicative 
space (Віротченко 2013; Hall 1968; Knapp \& Hall 2002), which is in the focus of attention in the present study.

Cognitive linguistics proceeds from the assumption that meaning is constructed in the process of communication (Chandler 1994; Croft \& Cruse 2004; Foulger 2004; Manerko 2016), and our perception of the communication environment contributes to the process of sense-making considerably. Previous cognitive linguistic research has offered a number of theoretical tools to be used in exploring the process of sense formation, for example, frames (Fillmore 1976; Wendland 2010), Idealized Cognitive Models (Hilferty 2001; Lakoff 1987), image schemas (Hart 2017; Johnson 1987; Lakoff 1987; Mandler \& Canovas 2014). Thus, cognitive linguistics has opened up new lines of research into the vast area of studying movement in the personal space as verbalized in a natural language.

My research is underpinned by the theory of Image Schemas (Johnson 1987; Lakoff 1987), which was developed primarily to emphasize the bodily, sensory-motor nature of various structures of our conceptualization and reasoning. Lakoff defines image schemas as relatively simple structures that constantly recur in our everyday bodily experience (CONTAINERS, PATHS, LINKS, FORCES, BALANCE, etc.), and in various orientations and relations (UP-DOWN, FRONT-BACK, PART-WHOLE, CENTER-PERIPHERY, etc.) (Lakoff 1987). Here we deal with schematic structures, which are at work in our perception, bodily movement through space, and physical manipulation of objects (Johnson 1987).

My research throws light on some very basic image schemas. Firstly, it is THE SOURCE / PATH / GOAL IMAGE SCHEMA (Johnson 1987; Lakoff 1987), which presupposes that we are in one place when we start to move, over time we change location; when we stop moving, we are usually somewhere different than where we started. Then there are THE PART / WHOLE AND THE CENTER / PERIPHERY IMAGE SCHEMAS. 
In my study, alongside with traditional structural methods of analysis (the distributional (Кобозева 2000) and system analyses (Ломтев 1976), I have applied such methods of cognitive linguistics as the image-schematic (Johnson 1987; Lakoff 1987) and conceptual analyses (Earl 2005). Through these methods, I have investigated the distributive potential of verbal constructions of motion in space, identified their differential semantic features, and specified the concept of communicative space and its image-schematic structure. The research sample comprises 1200 text fragments extracted using the continuous sampling method from American and British texts of the $20^{\text {th }}$ century of various genres, the total number of pages being over fifteen thousand. The fragments include linguistic expressions, which describe motion in communicative space. These consist of verbs with postpositions, adverbs or nouns and prepositions. In the following sections, my aim is to provide a definition for the scientific concept of space, elucidate the content of the everyday concept of space as presented in cognitive linguistic studies, define communicative space constituents, and establish the image-schematic structure of motion in communicative space.

\section{Capturing the notion of space scientifically}

Space is a fundamental notion of human thinking that represents a diversified nature of the world's existence in its inhomogeneity. Countless things and objects that simultaneously exist in human perception build up an elaborate spatial image of the world, which is an essential precondition for any type of human activity. In modern humanities, the spatial metaphor is applied to various conceptual spheres. For instance, linguists use the term "communicative space" to denote the space where human communication takes place.

The formation of the scientific notion of space has undergone the following stages. The concept of space goes as far back as the mythopoetic world image. The mythopoetic concept of space endowed it with the following features: inseparability from time, inextricable connection with objects that constitute space and arrange its structure, 
remoteness of space from what does not refer to it, composition (decomposition and connection) (Кубрякова 2004; Топоров 1983).

In the Middle Ages space was viewed in a specific way: the word spatium had another meaning - length, "interspace", locus denoted a place occupied by a certain object, but not an abstract space.

During the Early Modern period (the $16^{\text {th }}$ century) space was deprived of specificity and boundaries, and came to be considered as an abstraction, which was homogeneous and opposed to things. A human was believed to exist in space as a body among other bodies (Горина 2009; Топоров 1983).

In the $17-18^{\text {th }}$ centuries, the development of natural sciences stimulated the emergence of new scientific concepts of space. Isaac Newton came to distinguish two types of space: absolute space, which remains unchanged and is motionless, and relative space, which is a moveable part of the latter. Relative space is singled out by human perception, which depends on the observer's position relative to the objects observed.

Nowadays space is viewed as the distance from a person to the object of contact, as a stereosequence of objects, which coexist in time. The concepts of space and substance belong among the main existential categories; in this context, space is viewed as a container, which holds a human subject and everything that he perceives around and in front of him, it is an environment of all things present, an "emptiness", which is filled with objects and people (Кубрякова 2004).

In the scientific world image, which synthesizes data obtained by philosophy and natural sciences, space is endowed with the following features: inextricable connection with time and motion; dependence on structural relations and processes of development in material systems; length (location and coexistence of different elements - points, segments); a possibility of adding a certain element to a given element; continuity 
(absence of "gaps" in space); relative discontinuity (coexistence of separate objects and systems, which have certain dimensions and boundaries) (Кобозева 2000). The characteristics of space are divided into metric ones, which can be measured (dimensions, distances between objects) and topological (continuity, symmetry / asymmetry) (Топоров 1983: 241). Space is viewed, firstly, as a structure that is represented by such invariants as a region, a flat surface, arrangement of objects relative to one another, a distance. Secondly, space can be one-dimensional (possessing length), two-dimensional (possessing length and height), or three-dimensional (possessing three dimensions - length, height, and width) (Кобозева 2000).

Psychological distance is egocentric: its reference point is the self in the here and now, and the different ways, in which an object might be removed from that point - in time, in space, in social distance, and in hypotheticality - constitute different distance dimensions. Transcending the self in the here and now entails mental construal, and the farther removed an object is from direct experience, the higher (more abstract) the level of construal of that object (Trope \& Liberman 2010).

According to Construal level theory (Fiske \& Taylor 1991; Taylor 1995), people traverse different psychological distances by using similar mental construal processes. Because the various distances have the same egocentric reference point, they should all be cognitively related to each other and similarly affect and be affected by the level of construal. As the psychological distance increases, construals would become more abstract, and as the level of abstraction increases, so too would the psychological distances people envisage. Construal levels thus expand and contract one's mental horizon.

The concept of space is also an object-matter of present-day linguistic research. Scholars analyze the conceptualization of space in different languages, specifically, separate words, word classes, and syntactic structures (Кустова 2000; Рожанский 2000; Chuang 2017; Lander \& Haegeman 2016; Levinson \& Wilkins 2006); describe 
different types of conceptualization of spatial relations (Кубрякова 2004; Лебедева 2000; Подлесская 2000; Nijk 2017); study parameterization of space and its types (Болдырев 2000; Гак 2000; Горина 2009; Кобозева 2000; Тошович 2000); analyze spatial metaphors (Булыгина 2000; Мечковская 2004; Radden 1996). Researchers also study the linguistic world image of space and its cultural specificity (Croft \& Cruse 2004; Fauconnier 1997; Hebert \& Feist 2017; Taylor 1995), analyze spatial words and concepts that constitute the category of space (Clausner \& Croft 1999; De Knop 2016; Evans 2006; Izutsu 2016; Lin 2017; Samedova 2016; Stefanowitsch 2013; Vis 2009). Semanticists and cognitive linguists (Апресян 1995; Караулов 2001; Кобозева 2000; Кубрякова 2004; Подлесская 2000; Croft \& Cruse 2004; Dirven \& Verspoor 2004; Talmy 1985) carry out research into the methodology of space analysis and description.

\section{The concept of space in cognitive linguistic studies}

For cognitive linguists, space is "the most important aspect of the world model, a characteristic of length, structural properties, coexistence, interaction, coordination of elements of a separate culture and corresponding relations between cultures, meaning of the structural organization of cultures" (Пигалев 1998: 141).

Space is an environment of communicative activity, a necessary element for perceiving the world, a way of differentiating objects. Cognitive linguistic analysis of the concept of space as captured in a natural language reveals a number of its properties, which have until recently remained outside the scope of scholarly interest but which are important for those who consider space from the point of view of common sense. An everyday idea of space in fact comes down to enumerating "things" placed in it taking into account the orientation of one thing to another. Thus, a traditional space is a space filled with objects. It is organized by things, discrete, constitutive, and divided into segments, which relate to the objects that organize it (Кобозева 2000: 151).

To the backstage cognition, the value of space is determined by an obstacle, which hinders a human subject from entering the space, and this enhances the value of the 
latter. Theoretically, two types of space can be distinguished - the natural one and the closed one. The space of the first type is a natural location, the so-called boundless space characterized by a specific perspective and fuzzy boundaries. The space of the second type, the closed one, is characterized by clear boundaries. This space is subjective; it is created by a human subject, and thus is a reflection of his character and worldview (Манерко 2002). The latter type of space serves as a basis for communicative, or personal, space.

Space perception comes to allotting a patch of space within certain boundaries, which are determined by the sensory perception abilities of the observer, usually visual and tactile. For a human subject, the boundaries of space go beyond the limits of his sensory perception, expanding in the process of perceiving this space. These characteristic features of space depend on the individual's psychological characteristics and reflect the degree of his integration into the world. In any case, a person's idea of space presupposes motion, more specifically, the motion of the organs of perception (visual perception becomes the basis of space perception, which does not reduce the significance of other analyzers (hearing, smell, taste)). Space is the entity "inside which people, things, the landscape are situated". It is physical motion through some territory (an empirical perception of space is the perception of length, separateness, and remoteness of things, it is identifying the idea of the molded world, its harmony and order); it is motion of thought (the perception of space as a creative beginning of the world and potential energy) (Лебедева 2000: 93).

In a natural language, a mental representation of space, whatever its source, is transformed into text. Interpreting the text, the reader is able to construct a mental representation, which matches (to a certain degree) that of the author of the text. Here transduction takes place: visual information turns into verbal one, which has totally different principles of organization. In the context of integrated models, this transformation appears to be a specific case of moving from reality through its mental representation to the corresponding text. 
Naïve conception of space gives preference to topological linguistic units over metric units, which is suggested both on the macro level of text semantics and on the micro level of lexical semantics (words and structures, which are means of encoding space properties and relations). On the macro level, one can observe the absence of exact quantitative characteristics of the size of objects, distances between them, angular measures. On the micro level, the "topology" of the everyday concept of space is mostly reflected in the semantics of spatial prepositions, which idealize spatial relations between them, abstracting them from both their form and the distance between them (Кобозева 2000: 151-155).

Linguistic world image captures the knowledge of the world. This can be seen both in scientific terms and in non-terminological linguistic units that denote ways of spatial perception of the world (lexical and phraseological units, precedent texts, etc.). The array of these elements does not make a consistent, complete world image: rather they form a mosaic, a jigsaw puzzle, and sometimes even a contradictory linguistic image of the world, which is nationally coloured (Караулов 2001: 128-129). In the linguistic world image, space is not homogenous: there are fragments, which are "ours" or "theirs", close or distant, known or unknown, assimilated or non-assimilated, accessible or inaccessible, important or unimportant (Кустова 2000: 48). Spatial relations are a cluster of universal binary oppositions, which determine not only a component connected with spatial communication and expressed by different language signs, but also a component of the socio-cultural space (Привалова 2005: 154-156).

Spatial relations are considered to be a fragment of the naïve world image:

Language meanings can be connected with separate facts of reality not directly, but by means of reference to separate details of the naïve world image. As a result, there is a basis for establishing universal and national characteristic features in semantics of natural languages, some fundamental principles of language meaning formation, and thus there emerges a profound commonness of facts which seemed to be different before (Апресян 1995: 630). 


\section{Communicative space constituents}

An important aspect of analyzing space as manifest in a natural language is to take into account the anthropocentric factor. Anthropocentricity of space is suggested by the presence of a human subject in a communicative situation, i.e. the speaker, the listener, a third party. It is the human subject who chooses spatial references and in this way "animates" the space, which is interpreted, perceived by a person, and determined by the way objects coexist (Подлесская 2000: 98; Топоров 1983: 242).

Linguistic works, devoted to the study of space, introduce the concepts of personal sphere and communicative space in order to capture an important aspect of human communication, namely, that communicants create a certain communication space where they are located relative to each other. Communicants' location in space can bring communicants closer or, on the other hand, to distance them, which influences their communicative goal realization.

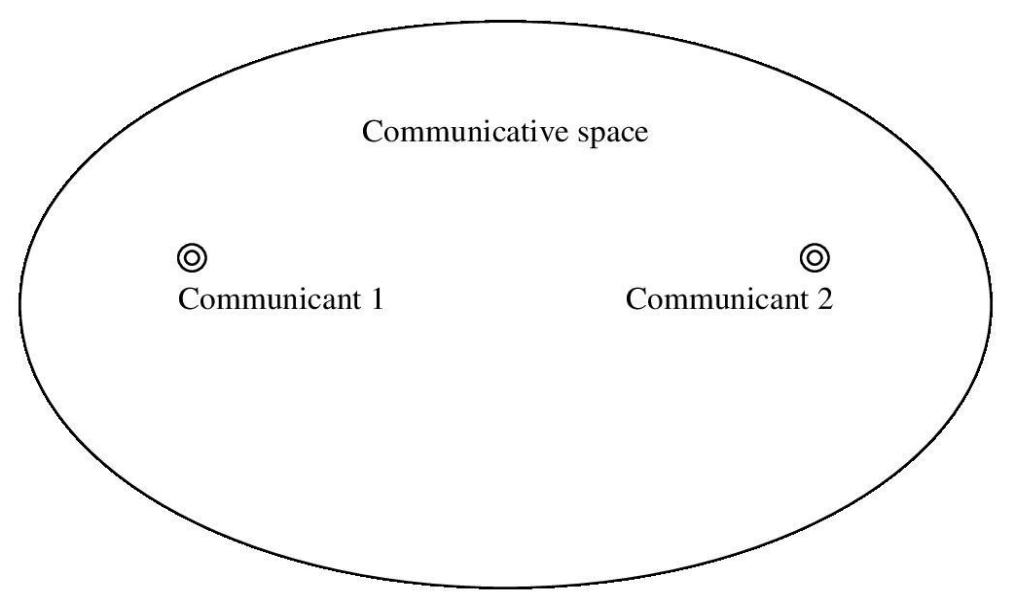

Figure 1. Communicative space and communicants' location in it

Producing a statement, a communicant creates communicative space around him. In modern linguistics, communicative space is viewed as an imagined sociopsychological environment where an appropriate communicative model is built, where communicants are located during their communicative interaction, and where they produce their messages (Орбан-Лембрик 2003; Berne 1980; Blum-Kulka et al. 1989; 
Corsaro 1985; Gumperz 1982; Habermas 1984; Kedar 1987). Communicative space is a set of spheres of communication where a certain linguistic persona can fulfill his existential needs according to the linguistic, cognitive, and pragmatic rules accepted in a certain society (Прохоров 1999: 60).

The components of communicative space are as follows: at least two human subjects who interact in this space, a common communicative act, its characteristic feature being the intertwinement of the need for certain information on the part of the communicants, feed-back on how well the recipient has perceived the verbally coded information and the communicant's behavior; a shared information field (the information generated in the process of interaction (clarification, additional information), it is much deeper than the primary information, it can differ in its content from the previous information); schemes and phenomena that promote or prevent mutual understanding; the general idea of communicative interaction that promotes acceptance or rejection of information.

Communicative space has the following characteristics: integrality (the measure of communicative balance), structuredness (the measure of the intensity and complexity of the components' interrelation), autonomy or functional homogeneity of the structural components (the place of each component in the communication process, the number of variants, which communicants can use when choosing means and ways of communicating information and reaching the communicative goal), formation of communicative positions and dispositions of communicative partners (ОрбанЛембрик 2003).

In communicative space, there is a sphere of "us", and there can be a few such spheres, varying from the narrowest, which includes the family, relatives, friends, to the broadest, which may include anybody. Communicative space can be provisionally divided into the spheres of a positive and negative emotional-psychological contact since mechanisms of distancing / approaching (alienation, familiarity, humiliation, 
exaltation, etc.) are at work in the communication process. The location of communicants in this space (with regard to the social and psychological constituents of distance) determines the choice of strategies and tactics, which influence the way of expressing one's will and thought. Violation of standard strategies or their inner inconsistency can cause a conflict. Configurations of communicative space can take different forms since both communicants' intentions of distance changing can coincide or differ (Солощук 2006).

The central category of communicative space is the communicant, the subject of cognition - the "SELF" which is surrounded by space and which constitutes its center (Бахтин 1979: 34-35). He always places himself in the center of communicative space, he does not see himself, but sees everything that surrounds him, sees and touches the "NON-SELVES" and the boundaries, which sets him apart in the outer world (Бахтин 1979; Лебедева 2000).

Thus, communicative space consists of personal spaces of discursive personalities, which are those of the addresser and addressee, which have a center and periphery with moveable boundaries.

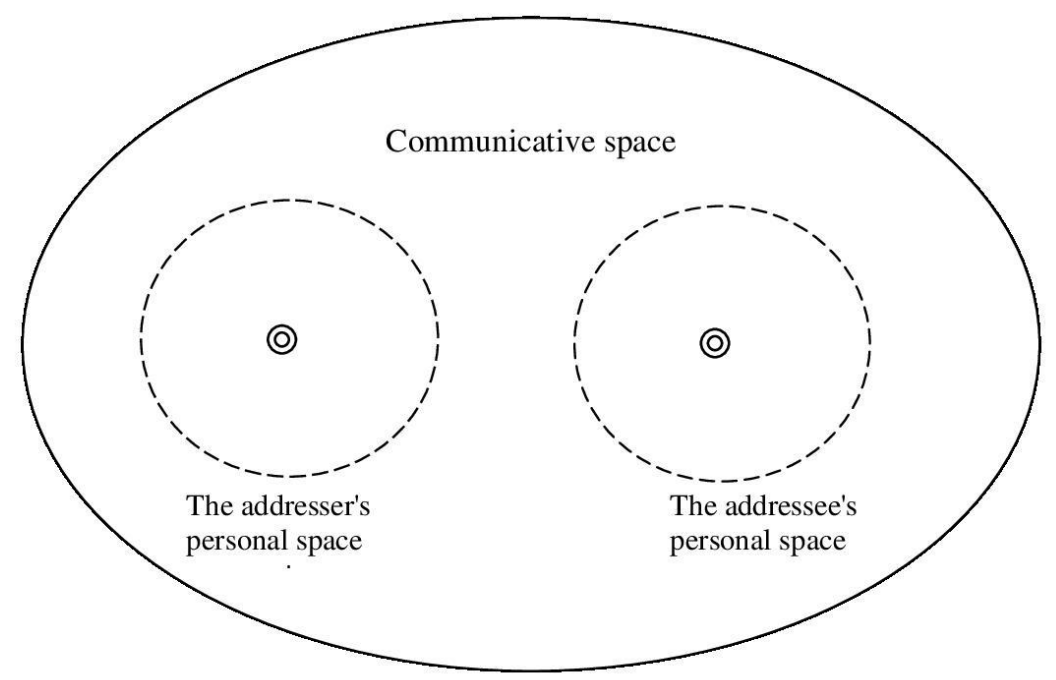

Figure 2. The addresser's and addressee's personal spaces within communicative space

The category of the speaker is central in the spatial deixis, and that is why in descriptions of the spatial component we can find descriptions of approaching or 
moving away from the interlocutor (Fillmore 1971). The constituent "SELF" arranges the semantic space of the utterance and the system of linguistic units, influences the interpretation of the means of description of spatial orientation within communicative contact. The contraposition of "SELF" and "NON-SELF" is the main opposition that organizes the deictic vocabulary of the closer (proximal) and the farther (extremal) deixis (Апресян 1995: 631). The semantic features of the words connected with spatial orientation are determined by how a person interprets his environment.

The study of how space is actualized in language will, on the one hand, point out means for the efficient description of spatial information and, on the other hand, throw light on the nature of the psychological processes of human conceptualizing of spatial information. Proper actualization of spatial semantics is a topical task for developing the code sets that enable access to visual information by means of language.

Spatial categorization is the process of using spatial parts of speech that carry implicit knowledge of space, which results in the development of specific spatial expectations of the communicant's "behaviour". Revealing the specificity of the communicant's language perception based on categorization analysis makes it possible to specify deep types of the communicant's orientation in space. Spatial relations are presented in different ways in different world images because semantic description of the spatial concept is shaped by national-cultural specifics of linguistic consciousness (Привалова 2005).

The primary means of personal space verbalization are deictic units (spatial prepositions and adverbs) that provide reference to the object's location relative to some reference point (static location) or a seme of reference to motion (approaching or moving away from) relative to a certain reference mark (dynamic location).

When expressing motion in space by means of language, the mechanism of changing the nonverbal into the verbal switches on. This brings us to the social semiotic concept 
of transduction that is remaking of meaning involving a move across modes - a process, in which "meaning material" is moved from one mode to another. A shift across modes involves the use of different semiotic entities of the mode, into which meaning materials are moved. Transduction involves a change in the recourses available for making meaning material, with profound implications for meaning. Additional or alternative cultural meanings and practices may shape the transductive process (Jewitt et al. 2016).

Communicants perceive changes in space not only empirically, but also theoretically, and verbal labels of motion in space contribute to it. These expressions are treated as the verbalization of different aspects of communicative situations. In order to capture differences in construing the situations of motion in the English language, we rely on the concept of image-schemas, which are considered in more detail in the following section.

\section{Image-schematic structure of motion}

Image schemas are the recurring patterns of our sensory-motor experience by means of which we can make sense of that experience, and reason about it, and that can also be recruited to structure abstract concepts and to carry out inferences about abstract domains of thought (Johnson 1987; Lakoff 1987).

The image schema is viewed as a structure in the cognitive processes that describes patterns of our understanding and cognition. Image schemas develop from our bodily interactions, from language experience, and historical context. They are schematic descriptions of the most typical patterns of our physical experience (motion, left-right, power, container, direction). They accumulate our experience into certain structures that align empirical facts on the level of physical perception and motion (Johnson 1987; Lakoff 1987). One and the same image schema can be actualized in different cognitive domains as the inner structure of each image schema can be rethought metaphorically. Lakoff holds that image schemas structure our experience on the pre-conceptual level, 
and metaphors are motivated by those structures that form an integral aspect of our everyday experience based on physical feelings (1987).

A certain part of any image schema can be described by different units, which is confirmed by Langacker's theory of "active zones". The important aspect of active zones is the variety of possible linguistic manifestations and the motivational link between meaning and form in each existing possibility (1987).

Thus, to describe motion in space in the English language we use units that express different aspects of such motion: "to move where to", "to move how", "to move wherefore", "to move where from and where to".

Motion is target-oriented, dependent on situations, determined by the necessity to change the communicant's location. According to Talmy, there is an abstract situation of motion, which includes a number of constituents: "a figure", that is an object of motion, "background", relative to which the object moves, "path" that includes the starting point and the stopping point of motion, etc. Their correlation in space changes visually: the figure moving from the background follows a certain path that is a set of mentally connected points in space, where the object has been located (1985).

So, motion in space can be actualized by the formula suggested by Gak (Гак 2000): $\mathbf{M}=\mathbf{O}+\mathbf{V}+\mathbf{r}+\mathbf{L}$

where $\mathbf{M}$ - motion in space, $\mathbf{O}$ - the object located in space, $\mathbf{V}$ - the verb, whose meaning can have a spatial seme (these are primarily verbs of location and motion), $\mathbf{r}$ - the localizer's operator, in our case expressed by postpositions, $\mathbf{L}$ - the localizer, that is space or a point, which the communicant tries to reach.

Verbs of motion that describe changes in space refer to the lexical-semantic field of spatial acts and positions (Тошович 2000: 163-165), their common seme being "location and change of the communicant's location as the result of motion" (Lindner 
1983). Postpositions, functioning as the localizer's operators, are a structural unchangeable part of speech, a word-formative element that makes a single whole with the verb (Inagaki 2001; Palmer 2004). Losing its primary meaning or keeping it partially, a postposition changes, specifies, complements the verb meaning, which it refers to. Postpositions modifying the verb are indicators of the direction of the communicant's motion.

Thus, functioning as a unified whole, verbs of motion and postpositions constitute verbal constructions of motion in space (VCMS). Considering syntactic-semantic features of VCMS, we distinguish the following structural-semantic models that correspond to the structure of the used constructions:

Vmov + postpos - the model describes VCMS consisting of the verb of movement and the postposition (the woman stepped forward, she swung towards, he shrank back, the man sank back);

Ving mov + postpos - the model describes VCMS consisting of Participle II of movement and the postposition (he burst out, leaning forward; he said, coming toward; she smiled, bending towards);

$\mathbf{V}+(\mathbf{A d j})+\mathbf{N}+\mathbf{p r e p}+\mathbf{s m b}-$ the model describes VCMS consisting of the verb and the noun, which can be modified by an adjective or a postpositional preposition (he took a tentative step to her, she closed the distance).

Thus, VCMS actualizes THE SOURCE / PATH / GOAL SCHEMA that has distinct structural constituents expressed by different language units:

1. The structural constituent - the direction of motion - forward is actualized by the following VCMS: to swing toward, to take a step toward / to, to step to / toward, to lean forward / closer, to jerk toward, to come forward, to bend towards, the direction of motion - back is actualized by the VCMS: to shrink back, to sink back, to swing away/back/from, to lean back, to retreat a step. One and the same direction of motion can have various kinds of verbal expression: the degree and intensity of motion varies. 
2. One and the same verb can describe different directions of motion: the semantic meaning of the verb depends on the semantics of the element it is accompanied by. The verb itself does not actualize the direction of motion without a context, its semantics depends on the semantic nature of the elements that express the direction of motion and that modify this verb (a verbal postposition): to lean forward / back, to come to / back, to swing towards / backwards.

The structural constituent of THE SOURCE / PATH / GOAL SCHEMA - intensity of motion - can be actualized by units of different degrees of explicitness. For instance, forward is described in the range from a sharp jerk to a smooth movement:

\section{a sharp jerk}

- to jerk toward smb

- to take a distracted step

- to lean urgently forward

- to lean quickly forward

- to swing toward smb

- to step toward smb / forward

- to go up to smb

- to take a slow step toward smb

- to come slowly toward smb

a smooth movement

The degree of explication of movements is expressed both by the verb itself ( $\underline{\text { to jerk }}$ ), and by other lexical units that accompany it (to take a distracted step, to come slowly).

Moreover, a multiword unit can be reduced to one word. For instance, to describe a quick movement in communicative space, it is possible to use the VCMS to take a distracted step, but it is also possible to replace it with one verb - to jerk. 
The lexical meaning of the VCMS describing motion has a double nature. On the one hand, it includes a semantic component, which means a physical notion, a process of motion and a way of motion (to lean, to bend, to take a step, to step, to jump). On the other hand, VCMS have a quantity component showing how big the measured space is: the communicant makes a movement whose length equals one step (to take a step), or a movement limited by the upper part of his body (to lean).

It is noteworthy that the diversity of lexical stylistic devices and variation of forms are not characteristic of the VCMS, they are lexically and structurally unvaried.

In the further sections, I will discuss how THE SOURCE / PATH / GOAL SCHEMA, THE PART / WHOLE SCHEMA, AND THE CENTER / PERIPHERY SCHEMA are actualized by verbal constructions of movement in space.

\section{THE SOURCE / PATH / GOAL SCHEMA underlying the semantics of verbal constructions of motion in space}

The VCMS describe the direction of changes in the spatial location of the communicants, specify intensity and the speed of changes in personal space, scale the communicant's motion and in this way actualize THE SOURCE / PATH / GOAL SCHEMA. This image schema is activated by all the VCMS as their structure contains all the constituents of THE SOURCE / PATH / GOAL SCHEMA.

\subsection{FORWARD and BACK as binary oppositions}

1. The structural constituent of THE SOURCE / PATH / GOAL SCHEMA is the direction of motion - FORWARD, so we distinguish the VCMS describing the communicant's orientation to the stopping point (a lative motion of the communicant to the interlocutor):

V/ing mov + postpos (smb): to advance to / forward / toward smb, to approach smb, to back to smb, to bend toward / over, to bound towards smb, to cling to smb, to come toward / to / forward / close to smb, to draw to smb / closer, to edge closer, to fling 
oneself to, to go up to smb, to hurry to smb, to jerk to / toward smb, to lean forward / toward smb / closer to smb, to leap forward, to limp to smb, to move toward / forward I to / closer to smb, to pull closer, to push forward, to rock forward, to run to smb, to rush forward, to shrink closer to smb, to sidle closer, to sit forward / close to smb, to slump forward, to spring to smb, to start toward smb / forward, to step toward smb / forward, to stride toward smb, to stroll closer, to sweep toward smb, to throw toward smb, to tower over smb, to trip forward smb, to turn to smb.

V/ing (mov) + N (+ postpos + smb): to advance a step, to close the distance / the space between smb, to take a step toward smb.

Among the VCMS describing the communicant's orientation to the stopping point, the most frequently used one is the pattern of the verb to lean and the postpositions forward / toward / closer -V/ing mov + postpos (smb), which is shown in Table 1:

Table 1. VCMS describing the communicant's orientation relative the stopping point

\begin{tabular}{|l|c|}
\hline \multicolumn{1}{|c|}{ VCMS } & Usage frequency \\
\hline to lean closer / forward / toward / & $40 \%$ \\
\hline to come close / forward / to / toward & $11 \%$ \\
\hline to move closer / forward / to & $8 \%$ \\
\hline to step forward / toward / to & $7 \%$ \\
\hline to take a step to / toward & $7 \%$ \\
\hline to go to & $6 \%$ \\
\hline to walk forward / to / towards & $4 \%$ \\
\hline to stride toward & $4 \%$ \\
\hline to swing toward & $3 \%$ \\
\hline to turn to & $3 \%$ \\
\hline to advance forward / to / towards & $2 \%$ \\
\hline to sit forward & $2 \%$ \\
\hline to start toward & $2 \%$ \\
\hline to bend forward / toward & $1 \%$ \\
\hline
\end{tabular}

It is noteworthy that the direction of motion is described only by postpositions: the verb expresses just the beginning of motion, whereas the postposition constitutes the 
direction of motion in the communicative space.

THE GOAL, the object that the communicant approaches, is syntactically explicated only in $43 \%$ of the VCMS, though semantically it is always present. This can be explained by the fact that dialogic communication implies two interacting communicants: the addresser and the addressee, thus it is clear that the addresser's motion is taking place in the addressee's personal space and vice versa.

2. The structural constituent of the THE SOURCE / PATH / GOAL SCHEMA - the direction of motion - BACK is actualized by the VCMS describing the communicant's orientation to the starting point (an elative motion of the communicant from the interlocutor):

V/ing mov + postpos (smb): to back away from smb, to draw away / back / from smb, to drive away, to edge away, to fall back, to fling from smb, to hang back, to inch away, to jerk away, to lean back / backward, to lie back, to move away / from smb, to pull back / away, to settle back, to slide away, to reel away from smb, to relax back, to shrink away/ backward / from smb, to sink back, to slip away, to sit back, to step away / back, to swing away from smb, to turn away / back, to walk away;

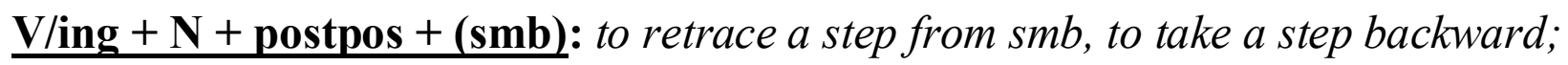
V/ing (mov) + smb + postpos: to hold smb away, to push smb away from, to wave smb away.

The usage frequency of the VCMS describing the communicant's orientation to the starting point is shown in Table 2:

Table 2. VCMS describing the communicant's orientation to the starting point

\begin{tabular}{|l|c|}
\hline \multicolumn{1}{|c|}{ VCMS } & Usage frequency \\
\hline to lean back/ backward & $30 \%$ \\
\hline to turn away / back & $10 \%$ \\
\hline to step away / back & $7 \%$ \\
\hline to back away & $6 \%$ \\
\hline to sit back & $6 \%$ \\
\hline to draw back & $5 \%$ \\
\hline
\end{tabular}




\begin{tabular}{|l|l|}
\hline to pull back & $5 \%$ \\
\hline to shrink away from smb / backward & $5 \%$ \\
\hline to move away & $4 \%$ \\
\hline to walk away & $4 \%$ \\
\hline to retrace / to retreat a step & $3 \%$ \\
\hline to edge away & $2 \%$ \\
\hline to hold smb away & $2 \%$ \\
\hline to push smb away from smb & $2 \%$ \\
\hline to settle back & $2 \%$ \\
\hline to swing away from smb & $2 \%$ \\
\hline to take a step backward & $2 \%$ \\
\hline to drive away & $1 \%$ \\
\hline to inch away & $1 \%$ \\
\hline to slide away & $1 \%$ \\
\hline
\end{tabular}

The most frequently used VCMS describing the direction BACK is to lean backV/ing mov + postpos. Motion of this kind is often used during communicative interaction that is characterized as a small-talk; in this case the communicant who increases the communicative distance takes a sitting position.

$19 \%$ of the VCMS describing the communicant's orientation to the starting point contain the syntactically expressed starting point, i.e. the object, the communicant moves away from, is not syntactically compulsory, though it is always semantically implied.

\subsection{An OBSTACLE as a constituent of THE SOURCE / PATH / GOAL SCHEMA}

The structural constituent of THE SOURCE / PATH / GOAL SCHEMA - the OBSTACLE - is actualized by the VCMS describing the communicant's orientation to the passing point (the communicant's motion relative to inanimate objects):

V/ing mov + across/over + obj: to lean across the table, to lean over the table, to stride over the desk. 
These VCMS are not numerous and they always contain such postpositions as across, over. The obstacle, always an inanimate object (in my sampling), described by these VCMS is a part of the PATH, which the communicant covers moving towards the interlocutor.

Actualizing of the PATH by the obstacle takes place when the communicative space is obstructed by an item of furniture, in most cases by a table. If the object is perceived by the communicant as an obstacle to establishing communicative interaction, the speaker tries to do away with it, and then he moves directly to the interlocutor. Motion of this kind is actualized in $3 \%$ of the total number of examples.

So, the VCMS describe the communicant's orientation to the stopping point in $60 \%$ of the total number of examples, and the VCMS describing the communicant's orientation to the starting point are used in $37 \%$. Thus, shortening the distance has a more expressive character, more semantic-pragmatic informational content and is more frequently used in different communicative situations of dialogic discourse.

\subsection{Aspectuality of motion as a type of schematic structure in language}

The VCMS actualize the MANNER of motion. The latter can take the form of an IMMEDIATE action, which happens within a moment that is impossible to decompose, and which does not imply a process that has a continuous character. "Immediate" (Плунгян 2000), or momentary, verbs express an action whose duration is too short or minimal.

These VCMS also describe a QUICK motion of the communicant. Such VCMS describe the communicant's attention to the GOAL and the point when the motion stops, when both the GOAL and the stopping point are close. Besides, it should be stressed that the verbs in these VCMS function as predicates, expressing instantaneity of the action, and are accompanied by adjectives and adverbs, which modify them and define the speed of the motion. Among the VCMS describing the communicant's 
orientation to the stopping point are the following:

M(noncont): Vmov (+ adj) + postpos + smb:

- to jerk toward smb

- to take a distracted step

- to lean urgently forward

- to rush toward smb

- to slump forward

- to fling to

- to spring forward

- to lean quickly forward

- to trip to

- to hurry to

- to swing toward smb

- to step toward smb / forward

- to go up to smb

- to take a step toward smb

- to come toward smb.

Contextual usage of VCMS of this group is illustrated by the following examples:

"I'm sorry, but that's not what we believe and I would like you to accompany me down to the station..."

Peggie suddenly stepped forward. "Just a minute, Constable".

"Peggie, you keep outta this" Sep turned to face her. "And didn't I tell the rest of you to go back to bed?" (Page 1994: 234).

"What do you do?"

"I teach English."

"Oh so do I."

"I lecture in Trinity."

James edged forward on his seat. "And what's your period?"

"Early seventeenth century" (Mac Laverty 1984: 93). 
The VCMS describing the communicant's orientation to the starting point and a quick motion in space are the following:

- to shrink backward

- to jerk away

- to swing away

- to step back

- to retreat a step.

Their usage is illustrated by the textual fragment below:

"Please, don't go, Mommy... please... I'll be good... I swear ... please let me come with уои..."

"Don't be ridiculous!" Eloise said and shrank backward, away from the child, in obvious revulsion. Just being that close to her, and having Gabriella clutch at her, made her want to run screaming out of the door (Steel 1998: 95).

A quick motion of the communicants in space makes communication more dynamic and unpredictable, due to which the communicant, who uses this technique, exerts a psychological influence on his interlocutor in order to achieve his communicative goal.

Motion that is not an immediate action is verbalized by the VCMS describing a NONIMMEDIATE action, which happens within a time span, which is decomposable into separate parts, and that means an unfinished action. The constituent verbs of these VCMS are used as Participle I and are accompanied by adverbial modifiers of the duration of an action describing the motion. These VCMS can also actualize a SLOW motion of the communicants in space. In this case, they do not contain adjectives that describe the action or give additional information about it. Among the VCMS expressing a non-immediate and slow shortening of the communicative distance are the following:

M(cont): Ving mov + postpos + smb: closing the distance, leaning toward smb / forward / closer, moving toward smb / forward, advancing to smb, starting towards smb, backing away from $s m b$. 
The examples below illustrate their functioning in discourse:

"I think Santa Claus or a friend of yours brought you an interesting present from New York, Cliffie," Marion said, bending toward him. "Want to see it now?"

"Oh - he can wait till tomorrow," Edith said. Cliffie looked all right, but was in a trance, Edith thought (Highsmith 1977: 44).

"This evening," said Liz, leaning forward, lowering her voice confidentially with mock importance across the yards of space, "we have butlers. And what I think is called catering. And vintage - I think it's vintage - champagne. Is that all right, Charles, is there such a thing as vintage champagne?" (Drabble 1987: 21).

The VCMS describing a non-immediate / slow increase of the communicative distance are the following:

- inching away

- sliding away

- slipping away

- backing away

The following example is an illustration of contextual functioning of one of them inching away:

"Do you still feel sick?" He squatted on his haunches beside her and tried to peer into her face, stroking her shoulder clumsily. "Were you sick?"

She shook her head, inching away from his hand. "No, I'm all right now, Tim, really I am. It passed off" (McCullough 1996: 106).

The communicants' slow motion in space contributes to a gradual decrease of communicative space, which tunes them up for perceiving information, creating an atmosphere of trust and closeness. 


\section{THE PART / WHOLE SCHEMA underlying the meaning of verbal constructions of motion in space}

Motion in space can be either whole-body movement or part-body movement, which falls within THE PART / WHOLE SCHEMA. From the viewpoint of integrity of the communicants' motion in space, we distinguish two groups of the VCMS, which embody this image schema: "integral" and "partitive" (the term of Toshovich) (Тошович 2000).

The integral VCMS describe the communicant's whole-body motion. Among such VCMS are the following: to advance to, to approach smb, to back to / away, to bound towards, to come toward, to edge away / closer, to fling oneself to, to go up to smb, to hurry to smb, to jerk to, to leap forward, to limp to smb, to move toward, to push forward, to run to smb, to rush forward, to shrink closer to smb, to sidle closer, to sit forward, to slump forward, to spring to smb, to start toward, to step toward, to stride toward smb, to stroll closer, to sweep toward smb, to throw toward smb, to trip forward smb, to swing to, to walk away / forward.

Partitive VCMS describe motion not of the whole body, but of its part, in this case we mean the upper part of the body. Among such VCMS are the following: to bend toward / over, to cling to smb, to lean forward / back, to sink back.

As mentioned above, partitive VCMS are not as numerous as integral ones because in the English language lexical units, which describe movement of the upper part of the body, do not demonstrate either lexical or stylistic variety of representation. On the other hand, VCMS actualizing partitive motion in space are most frequently used. It is accounted for by the fact that during communicative interaction with the starting sitting position of the communicant's motion, part-body movements emphasize the verbal message, bringing a significant meaning: they influence the meaning of the verbal message, the interlocutor and consequently reaching the communicative aim, as the example below shows: 
George leaned forwards to catch Terence's full attention. "How can you be sure they're not caused by being thrashed by your mother?"

Terence spoke very quickly. "There will always be problems between men and women and everyone suffers in some way" (McEwan 1990: 255).

The diversity of ways of actualizing whole-body motion in space is explained by various types of motion depending both on the speed of motion (to wriggle, to stroll, to run, to rush, to jerk), and on the manner of motion (to leap, to run, to sit, to trip, to walk).

\section{THE CENTER / PERIPHERY SCHEMA underlying the semantics of verbal constructions of motion in space}

THE CENTER / PERIPHERY SCHEMA conceptualizes motion in space depending upon how far the communicant moves: whether he moves within the minimal radius of his personal space, the center, and nucleus of which he is himself; or he moves into the periphery of his personal space. In the perspective of the classification of the VCMS describing the whole-body / partitive motion and immediate / non-immediate motion, we distinguish two more groups of the VCMS that actualize the limited and unlimited space of motion.

The limited space of motion, i.e. motion in the CENTER of the communicative space, is actualized by the VCMS, which also describe the immediate motion and the communicant's partitive movement, in other words, when the communicant's movement is limited by the upper part of the body:

Slim $=$ Vmov lim + postpos $(+\mathbf{s m b}):$ to lean toward $/$ forward $/$ closer to $\mathrm{smb}$, to bend toward / over.

Motion in the CENTER of the communicative space is also actualized by the VCMS containing the lexical unit step, which can be expressed either by the verb, or the noun: Slim: V(lim) (+ Nlim) + postpos (+ smb): to step toward smb / forward, to take a step 
toward smb, to step back, to retreat a step.

The unlimited space of the communicant's motion, i.e. motion in the PERIPHERY of the communicative space, is actualized by the VCMS, which firstly describe the nonimmediate motion, and secondly actualize the whole-part body movement. Thirdly, these VCMS do not contain the syntactically expressed element, which denotes the GOAL of motion:

Sunlim $=$ Vmov unlim + postpos $(+\mathbf{s m b}):$ to move toward smb, to come forward, to advance to smb, to start towards smb, to back away, etc.

\section{Structural elements of image schemas actualized by verbal constructions of motion in space}

Analysis of the VCMS from the viewpoint of their syntactic-semantic characteristics makes it possible to specify the occurrence of the structural constituents and spatial references of the image schemas.

9.1 Structural constituents of image schemas actualized by verbal constructions of motion in space

A common situation of motion implies that within a certain period of time its main participant (the object that moves in space or the object that is moved) successively changes his location. The points, which the communicant reaches moving in space, compose the integrated space. Within this space I distinguish four linguistically significant points: the OBJECT of motion; the point where the communicant was located when he started his motion (the starting point) - the SOURCE; the point where the communicant was located when he finished his motion (the stopping point) - the GOAL; and all those points where the communicant was located between the beginning and the end of his motion - the PATH. If we consider the object [O], the PATH [P], the SOURCE [S] and the GOAL [G] from the view point of their syntactic-semantic characteristics, they are constituents of the VCMS, which verbalize the communicants' motion in space. 
These constituents can be or can be not syntactically expressed in the VCMS, but can be reconstituted in a certain context.

I will consider each of the constituents from the viewpoint of its syntactic presence and function in the sentence.

1. The OBJECT $[\mathrm{O}]$ is always syntactically expressed in sentences, where motion in the communicative space is actualized. The object of motion is the communicant who either shortens the communicative distance, or increases it (Melanie [O] leaned back on the sofa; $\underline{\mathrm{He}}[\mathrm{O}]$ leaned forward). The syntactic functions it fulfills are the following:

1) the function of the subject:

Oliver leaned back in his chair across the desk;

2) the function of the object:

He dragged her face nearer to his.

2. THE SOURCE [S]. There are certain peculiarities of source actualization from the viewpoint of interdependence of shortening / increasing of distance and the means of actualization of this constituent. In the case of shortening the communicative space the source is often expressed by inanimate nouns: the communicant starts this motion from a certain point changing his sitting position for a standing one (She pushed herself up out of the chair $[S]$ and came towards him; He looked sharply at me, then rose from his chair [S] and took a step toward me...). In the case of increasing the communicative space the source is expressed by animate nouns or pronouns: the communicant starts his motion from the interlocutor moving away from him (April muttered something incomprehensible and moved a few steps from them [S]; Cliffie replied, flinging himself up at the other end of the sofa from Melanie [S]).

3. THE GOAL $[\mathrm{G}]$. The goal is syntactically expressed in sentences where changes of communicative space are actualized. There are certain patterns concerning the means of goal actualization. In the case of shortening the distance the goal is actualized by 
animate nouns or pronouns: the communicant approaches the interlocutor (Miss Fergusson saw the need to reassure me, and she leaned forward to me [G] and patted my knee). In the case of increasing the distance between the communicants the goal is actualized by inanimate nouns: the communicant seeks some support due to his inability to psychologically confront the opponent (Christopher leaned back against the windowsill [G] and closed his eyes; Lindsey leaned back in her chair [G], her brain whirling with conflicting emotions). Even when the goal is not syntactically expressed, it is expressed semantically (Leaning close, not sure what he was doing, Sandy softly asked...; I leant forward and said...). Thus, the semantic constituent of the VCMS the goal - is the interlocutor who the communicant approaches.

4. THE PATH $[\mathrm{P}]$ is syntactically expressed in sentences when both the source, and the goal are syntactically expressed, in this way we can trace the communicant's exact path (She affirmed, and leaned over the desktop [P] toward me; Jack leaned across the table $[P])$. However, if the path of the communicant's motion in space is not syntactically expressed, it is still possible to fix it. Having no clearly defined points of the path of the communicant's motion, but assuming that the communicant gradually approaches the interlocutor, it is possible to conclude that the communicant's path is the stretch from the start point of his motion (the point where he was located) to the stopping point (the interlocutor's location) (He looked sharply at me... and took a step toward me $[P] . .$. then he took another step to me $[P]$...looked into my face and laid his hand on my arm). Besides, it is possible to measure the length of the path of the communicant's motion: (he took a step toward me $[P]$...then he took another step to $\underline{m e}[P])$ - the length of the path of motion is two steps).

Thus, the VCMS actualize the image schemas that have certain constituents, which are not always syntactically and even semantically expressed: there are such descriptions of the communicant's motion in space, which do not imply indication of all the constituents. The syntactic absence of a certain constituent can fall under one of three cases: 
1) a fixed (semantically compulsory) constituent;

2) an omitted (semantically compulsory but syntactically optional) constituent;

3) an absent (semantic) constituent.

The occurrence of the image schemas' constituents is shown in Table 3:

Table 3. The occurrence of the constituents of THE SOURCE / PATH / GOAL SCHEMA

\begin{tabular}{|c|c|c|c|c|c|}
\hline The constituent & $\begin{array}{l}\text { The fixed } \\
\text { constituent }\end{array}$ & $\begin{array}{l}\text { The implied } \\
\text { constituent }\end{array}$ & & & $\begin{array}{l}\text { The total } \\
\text { number }\end{array}$ \\
\hline & & $\begin{array}{l}\text { The omitted } \\
\text { constituent }\end{array}$ & $\begin{array}{l}\text { The absent } \\
\text { constituent }\end{array}$ & & \\
\hline $\begin{array}{l}\text { The OBJECT of } \\
\text { motion [O] }\end{array}$ & $100 \%$ & $0 \%$ & & & $100 \%$ \\
\hline $\begin{array}{l}\text { The PATH of } \\
\text { motion }[\mathrm{P}]\end{array}$ & $3 \%$ & $97 \%$ & & & $100 \%$ \\
\hline $\begin{array}{l}\text { The SOURCE of } \\
\text { motion [S] }\end{array}$ & $10 \%$ & $90 \%$ & & & $100 \%$ \\
\hline $\begin{array}{l}\text { The GOAL of } \\
\text { motion }[\mathrm{G}]\end{array}$ & $39 \%$ & $42 \%$ & & $19 \%$ & $100 \%$ \\
\hline
\end{tabular}

The PATH of motion [P] is syntactically fixed in 3\% of the analyzed VCMS that constitute the communicants' motion in space. As for the situations of omission and absence of the constituent, it is viable to combine these two groups: on the one hand, we deal with the absence of both the syntactic, and the semantic actualization of the constituent. On the other hand, the communicant's motion always implies the path: from the communicant's location to the interlocutor's location. Thus, in $97 \%$ of the VCMS the PATH is implied.

The SOURCE [S] is syntactically fixed in $10 \%$ of the VCMS. It is also viable to combine the cases of omission and absence, because this constituent is not syntactically fixed, but on the other hand, we imply it: the source of motion is the communicant's 
location before he started to move. Thus, the SOURCE is an implied constituent in $90 \%$ of the VCMS.

The GOAL [G] is syntactically fixed in 39\% of the VCMS that constitute shortening of the communicative distance, when more than two interlocutors interact in the communicative process, and it is necessary to point out the communicant relative to whom the distance is shortened; or in situations of dialogic interaction, when the author aims at emphasizing the communicant who his opponent is approaching. When the distance is increased, the goal is fixed when it is expressed by inanimate nouns (items of furniture). The GOAL is an implied constituent in $42 \%$ of the VCMS, when the communicative distance of two interlocutors is shortened, and it is clear from the context, which of the participants of the interaction is an object of approach. The absence of this constituent is found in $19 \%$ of the VCMS that describe the communicant's moving out of the interlocutor's communicative space.

\subsection{Spatial references of image schemas actualized by verbal constructions of motion} in space

Following the classification of verbal references by Plungian (Плунгян 2000), who distinguished four classes of references of verbs of motion, I have analyzed the VCMS, which constitute the communicants' motion in communicative space, and distinguished three classes of spatial references: anthropocentric, objective, and gravitational.

1. Anthropocentric spatial references draw upon the significant type of asymmetry that is peculiar for animate objects: the essence of "the face". This spatial reference is used to specify the front zone of the topologic periphery, and in the case of orientation of dynamic situations it has an additional function, because it specifies the direction of motion: in common situations the person moves forward, that is the direction he looks in. 
The peculiar feature of the VCMS is that almost all of them contain anthropocentric spatial references, since during the communicative process the communicants' motions forward and back are the most significant ones.

Among the VCMS that contain anthropocentric spatial references $60 \%$ describe the communicant's motion forward (the pattern - Vmov + postpos): to edge forward, to bend towards, to lean forward / close / towards, to come towards, to step forward / toward / to, to advance to, to start towards, to swing to, to go up to, to move toward.

The direction forward is the primary one in the group of anthropocentric spatial references but not the only one, as a number of other directions are specified on its basis. One of such directions is back.

$39 \%$ of the VCMS describe the communicant's motion back (the pattern Vmov + postpos): to lean back, to back away, to ease back, to reel away, to sink back.

The meaning of "back" is more complicated: it is motion along the way already made but in the opposite direction (i.e. the motion when the former starting point is the stopping point).

Another type of anthropocentric spatial references - aside is off-type but rather interesting for analysis. This spatial reference is observed only in $1 \%$ of the VCMS that describe motion in space: to step sideways.

2. Objective spatial references denote any unit of the surrounding environment: elements of landscape (a mountain, a river), objects (a house, a table, a chair) that show both stable, and unstable positions. Both types of objective spatial references are boundaries of the communicant's personal space. During communicative interaction the communicants use objects with an unstable position in a freer way to specify, control, and protect their personal space. 
Among the VCMS, that actualize image schemas, 19\% contain objective spatial references, most of which are items of furniture that are located close to the person at the moment of communication: a chair, a table, a sofa. For instance, the objective spatial reference "a chair" is used in $26 \%$ of all spatial references: the spatial reference "a table" is used in the same percentage correlation (26\%).

$31 \%$ of the VCMS that contain objective spatial references actualize motion forward $($ the pattern $-\mathbf{V}(\mathbf{m o v})+\operatorname{prep}+\mathbf{N}(+$ postpos $+\mathbf{s m b}))$ : to lean over the desk top toward, to lean across the table. These combinations are found in situations that testify to the speaker's interest to the interlocutor. Trying to get the necessary information and having an obstacle on the way to the interlocutor, the communicant tries to approach the opponent.

Among the VCMS, that contain objective spatial references, 69\% actualize the communicant's motion back (the pattern $-\mathbf{V}(\mathbf{m o v})+\mathbf{p r e p}+\mathbf{N})$ : to lean back on the sofa, to sink back into a chair, to ease back in a chair, to lean back in a chair.

3. Gravitational spatial references actualize motion influenced by gravitation, i.e. down and in the opposite direction - up. Owing to their physical nature these references are used for actualization of the direction of motion, but not the points on the path of motion.

Though gravitational spatial references are listed as the most numerous ones in the system of verbal orientation, in my investigation of communicative motion in space these references are used in 7\% of all VCMS (the pattern $-\mathbf{V m o v}+\mathbf{p r e p}+\mathbf{N})$ : to get up from a chair, to raise from a chair, to push up out of a chair. As is seen from the examples, in most cases we find the reference "up". It is accounted for the fact that the motion "up" is a starting point of the communicant's motion toward the interlocutor. 
To sum up, having analyzed the VCMS and their spatial references, we can conclude that VCMS actualize image schemas, which contain anthropocentric spatial references, less often objective spatial references, mostly when increasing of the distance occurs, and gravitational spatial reference.

\section{Conclusion}

The study of space has been of great interest since ancient times, and it remains a matter of interest of today's linguistic research. Scholars apply different approaches to the study of space and ways of conceptualizing space relations. Much attention is given to meaningful changes of the communicant's personal space: implementing communicative interaction, communicants create a certain communicative space where they are located relative to each other. Their communicative space consists of personal spaces of discursive personalities, that is, the ones of the addresser and the addressee, which have the center and periphery with moveable boundaries.

This paper has considered the process of verbalization of movement in the personal space from a cognitive perspective. Specific features of verbal representation of movement in the communicative space in English have been brought to light by applying image schemas, which are schematic descriptions of the most typical patterns of our physical experience and which mold our experience as certain structures that align empirical facts on the level of physical perception and motion.

The image schematic structure of motion is actualized by verbal constructions of motion in space (VCMS), which consist of a verb and a postposition, or a verb and a noun, which can be modified by an adjective or a postpositional preposition.

The VCMS under consideration actualize THE SOURCE / PATH / GOAL SCHEMA as their structure contains all the constituents of the image schema. Within this schema, we distinguish binary oppositions of the direction of the communicant's motion forward and back. The direction of motion is described only by the postpositions: the 
verb expresses just the beginning of motion, whereas the postposition constitutes the direction of motion in the communicative space. The VCMS actualize an optional constituent of THE SOURCE / PATH / GOAL SCHEMA - the obstacle, a part of the PATH, which the communicant covers moving towards the interlocutor. The VCMS that describe the obstacle are not numerous; they always contain such postpositions as across, over, and the obstacle itself is mostly an item of furniture. The VCMS actualize the MANNER of motion. The communicant's motion can take the form of an immediate and quick motion when the GOAL is close. Such motion happens within a moment that is impossible to decompose. The VCMS that actualize the immediate motion function as predicates modified by adjectives and adverbs, which specify the speed of the motion. Non-immediate and slow motion happens within a time span, which can be decomposed. The verbs these VCMS consist of are used in the form of Participle I and are accompanied by adverbial modifiers of the duration of an action.

The VCMS actualize THE PART / WHOLE SCHEMA by describing the whole-body or the part-body movement of the communicant. Whole-body motion is verbalized by the integral VCMS, whereas part-body motion (motion of the upper part of the body) is actualized by the partitive VCMS. The partitive VCMS are not as numerous as integral ones because in English the set of lexical units, which describe motion of the upper part of the body, is rather limited. The diversity of ways of actualizing wholebody motion in space is explained by various types of motion depending on the speed and manner of motion.

THE CENTER / PERIPHERY SCHEMA conceptualizes motion in space depending upon how far the communicant moves: whether he moves within the minimal radius of his personal space (the center), or he moves into the periphery of his personal space. Motion in the CENTER of the communicative space is actualized by the VCMS, which describe the immediate motion and the communicant's partitive movement. Motion in the PERIPHERY of the communicative space is actualized by the VCMS, which describe non-immediate and whole-part body movement and do not contain the 
syntactically expressed the GOAL of motion.

In the paper, I also specified the occurrence of the structural constituents and spatial references of the image schemas.

Within communicative space, I distinguish four linguistically significant points: the OBJECT of motion; the point where the communicant was located when he started his motion - the SOURCE; the point where the communicant was located when he finished his motion - the GOAL; and all those points where the communicant was located between the beginning and end of his motion - the PATH. I considered each of the constituents from the viewpoint of its syntactic presence and functioning in the sentence. The PATH of motion is syntactically explicit in 3\% of the analyzed VCMS and is implied in 97\%. This constituent is semantically actualized, as the communicant's motion always implies the path: from the communicant's location to the interlocutor's location. The SOURCE is syntactically explicit in $10 \%$ of the VCMS and is implied in $90 \%$ as the source of motion is the communicant's location before he started to move. The GOAL is syntactically explicit in 39\% of the VCMS, when more than two interlocutors interact, and it is necessary to point out the communicant who changes the communicative distance. The GOAL is implied in $42 \%$, when it is clear from the context which of the participants of the interaction is an object of approach, and it is absent in $19 \%$ of the VCMS when the communicant leaves the interlocutor's communicative space.

I have also distinguished three classes of spatial references: anthropocentric, objective, and gravitational. Anthropocentric spatial references specify the direction of motion forward and back. $60 \%$ of the VCMS that contain anthropocentric spatial references describe the communicant's motion forward, and 39\% describe the communicant's motion back. Objective spatial references denote any element of the environment, the position of which can be stable or unstable. These spatial references are the boundaries of the communicant's personal space. 19\% of the VCMS contain objective spatial references, which are mostly presented by items of furniture. $31 \%$ of the VCMS that 
contain objective spatial references actualize the forward motion of a communicant, and $69 \%$ actualize his motion back. Gravitational spatial references actualize the motion influenced by gravitation - down or up. These references, mostly "up", are used for actualization of the direction of motion in $7 \%$ of all VCMS.

Thus, the cognitive approach to the analysis of English verbalization of motion in communicative space contributes to the development of the general theory of space. The cognitive oriented theory elaborated in the present research throws more light on the image schematic structure of motion in space and its actualization in English discourse.

\section{References}

Alcaraz-Carrión, D. \& Valenzuela-Manzanares, J. (2017). Temporal co-speech gestures: a comparison between spatial and non-spatial temporal expressions. In Book of abstracts. International cognitive linguistics conference: linguistic diversity and cognitive linguistics, 10-14 July 2017, Tartu, Estonia, p. 160.

Apresyan, Yu.D. (1995). Deixis in lexis and grammar and naïve world image. In The selected texts. Integral description of language and system lexicography. Moscow: Yazyki russkoj kultury, p. 629-650. / Apresyan Yu.D. Dejksis v leksike i grammatike i naivnaya model mira. In Izbrannyie trudy. Integralnoe opisanie yazyka i sistemnaya leksikografiya. Moskva: Yazyki russkoj kultury, s. 629-650. / Апресян Ю.Д. Дейксис в лексике и грамматике и наивная модель мира. In Избранные труды. Интегральное описание языка и системная лексикография. Москва: Языки русской культуры, с. 629-650.

Bakhtin, M.M. (1979). Esthetics of language art. Moscow: Iskusstvo. / Bakhtin M.M. Estetika slovesnogo tvorchestva. Moskva: Iskusstvo. / Бахтин M.M. Эстетика словесного творчества. Москва: Искусство.

Berne, E. (1980). Games people play: The psychology of human relationships. Harmondsworth: Penguin.

Blum-Kulka, Sh., Hause, J. \& Kasper, G. (1989). Investigating cross-cultural 
pragmatics: an introductory overview. In Cross-cultural pragmatics: requests and apologies. Norwood: Ablex, p.1-34.

Boldyrev, N.N. (2000). Expression of the doer's space and the observer's space in the utterance. In Logic analysis of language: languages of spaces. Arutyunova, N.D. \& Lyevontina, S.B. (eds.). Moscow: Yazyki slavianskoj kultury, p. 212-220. / Boldyrev N.N. Otrazheniye prostranstva deyatelia i prostranstva nabliudatelia v vyskazyvaniyi. In Logicheskij analiz yazyka: yazyki prostranstv. Arutyunova N.D. \& Lyevontina I.B. (red.). Moskva: Yazyki slavianskoy kultury, s. 212-220. / Болдырев Н.Н. Отражение пространства деятеля и пространства наблюдателя в высказывании. In Логический анализ языка: языки пространств. Арутюнова Н.Д., Левонтина И.Б. (ред.). Москва: Языки славянской культуры, с. 212-220.

Bulygina, T.V. (2000). Motion in space as a metaphor of emotions. In Logic analysis of language: languages of spaces. Arutyunova, N.D. \& Lyevontina, S.B. (eds.). Mocsow: Yazyki slavianskoj kultury, p. 278-288. / Bulygina T.V. Peremeschenie v prostranstve kak metafora emotsij. In Logicheskij analiz yazyka: yazyki prostranstv. Arutyunova N.D., Lyevontina I.B. (red.). Moskva: Yazyki slavianskoj kultury, s. 278288. / Булыгина Т.В. Перемещение в пространстве как метафора эмоций. In Логический анализ языка: языки пространств. Арутюнова Н.Д., Левонтина И.Б. (ред.). Москва: Языки славянской культуры, с. 278-288.

Chandler, D. (1994). The transmission model of communication. Available at: http://visual-memory.co.uk/daniel/Documents/short/trans.html

Chuang, H-J.R. (2017). A contrastive study on spatial relations: containment and support: an embodied cognition approach. In Book of abstracts. International cognitive linguistics conference: Linguistic diversity and cognitive linguistics, 10-14 July 2017, Tartu, Estonia, p. 222.

Clausner, T.\& Croft, W. (1999). Domains and image schemas. In Cognitive linguistics, 10 , p. 1-31.

Corsaro, W.A. (1985). Sociological approaches to discourse analysis. In Handbook of discourse analysis. Dijk, van T.A. (ed.). London: Academic Press, p.167-192. 
Croft, W. \& Cruse, D.A. (2004). Cognitive linguistics. Cambridge: Cambridge University Press.

De Knop, S. (2016). German causative events with placement verbs. In Lege artis. Language yesterday, today, tomorrow. The journal of University of SS Cyril and Methodius in Trnava, I (1), June 2016, p. 75-115. DOI: 10.1515/lart-2016-0002 Dirven, R. \& Verspoor, V. (2004). Cognitive exploration of language and linguistics. Amsterdam (Philadelphia): John Benjamin's Publishing Company.

Drabble, M. (1987). The radiant way. London: Penguin Books.

Earl, D. (2005). The Classical theory of concepts. In The Internet encyclopedia of philosophy. Available at: www.iep.utm.edu/conc-cl/

Evans, V. (2006). Lexical concepts, cognitive models and meaning-construction. In Cognitive linguistics, 17, p. 491-534.

Fauconnier, G. (1997). Mappings in thought and language. Cambridge: Cambridge University Press.

Fillmore, Ch.J. (1976). Frame semantics and the nature of language. Available at: http://www.icsi.berkeley.edu/pubs/ai/framesemantics76.pdf

Fillmore, Ch.J. (1971). Santa Cruz lectures on deixis. Bloomington: Indiana University Linguistics Club.

Fiske, S.T. \& Taylor, S.E. (1991). Social cognition. New York: McGraw-Hill.

Foulger, P. (2004). Models of the communication process. Available at: http://davis.foulger.info/research/unifiedModelOfCommunication.htm

Gak, V.G. (2000). Space beyond space. In Logic analysis of language: languages of spaces. Arutyunova, N.D. \& Lyevontina, S.B. (eds.). Moscow: Yazyki slavianskoj kultury, p. 127-134. / Gak V.G. Prostranstvo vne prostranstva. In Logicheskij analiz yazyka: yazyki prostranstv. Arutyunova N.D., Lyevontina I.B. (red.). Moskva: Yazyki slavianskoj kultury, s. 127-134./ Гак В.Г. Пространство вне пространства. In Логический анализ языка: языки пространств. Арутюнова Н.Д., Левонтина И.Б. (ред.). Москва: Языки славянской культуры, с. 127-134.

Gorina, A.V. (2009). Space and time as basic categories of the literary text (based on the novel "Free Fall" by W. Golding). Thesis for the Candidate Degree in Philology, 
Speciality 10.02.19 - Theory of languages. Krasnodar: Kuban State University. I Gorina A.V. Prostranstvo i vremia kak bazovyye kategoriyi khudozhestvennogo teksta (na materiale romana U. Goldinga "Svobodnoe padenie"). Dissertatsiya na soiskanie uchenoj stepeni kandidata filologicheskikh nauk, Spetsialnost' 10.02.19 - Teoriya yazyka. Krasnodar: Kubanskij gosudarstvennyj universitet. / Горина A.B. Пространство и время как базовые категории художественного текста (на материале романа У. Голдинга "Свободное падение"). Диссертация на соискание ученой степени кандидата филологических наук, Специальность 10.02 .19 Теория языка. Краснодар: Кубанский государственный университет.

Gumperz, J.J. (1982). Discourse strategies. Cambridge: Cambridge University Press. Habermas, J. (1984). The theory of communicative action. London: Heinemann.

Hall, E.A. (1968). Proxemics. In Current anthropology, 9, p. 83-108.

Hart, C. (2017). Image schema orientation in action verb semantics: An experimental study of transitive vs. reciprocal verbs. In Book of abstracts. International cognitive linguistics conference: Linguistic diversity and cognitive linguistics, 10-14 July 2017, Tartu, Estonia, p. 279.

Hebert, J.E. \& Feist, M.I. (2017). Separate spaces: A comparison of prepositional meanings in native and nonnative English speakers. In Book of abstracts. International cognitive linguistics conference: linguistic diversity and cognitive linguistics, 10-14 July 2017, Tartu, Estonia, p. 282.

Highsmith, P. (1977). Edith's diary. London: Penguin Books.

Hilferty, J. (2001). Maximality and idealized cognitive models: The complementation of Spanish tener. Available at: https://www.um.es/lincoing/jv/ 2001\%20ICMs\%20\&\%20tener\%20Lang\%20Sciences.pdf

Inagaki, S. (2001). Motion verbs with goal PPs in the L2 acquisition of English and Japanese. Available at: https://www.cambridge.org/core/services/aop-cambridgecore/content/view/S0272263101002029

Izutsu, K. (2016). Moving event and moving participant in aspectual conceptions. In Lege artis. Language yesterday, today, tomorrow. The journal of University of SS Cyril and Methodius in Trnava, I (1), June 2016, p. 116-162. DOI: 10.1515/lart-2016-0003 
Janzen, T. (2017). Shared spaces, shared mind: connecting past and present viewpoints in American sign language narratives. In Book of abstracts. International cognitive linguistics conference: Linguistic diversity and cognitive linguistics, 10-14 July 2017, Tartu, Estonia, p. 144.

Jewitt, C., Bezemer, J. \& O'Halloran, K. (2016). Introducing multimodality. New York: Routledge.

Johnson, M. (1987). The body in the mind: The bodily basis of meaning, imagination, and reason. Chicago: The University of Chicago press.

Karaulov, Yu.N. (2001). Language conscience as a process. Theoretical background of one experiment. In Word. The anniversary issue devoted to the $70^{\text {th }}$ anniversary of Prof. I. Tchervenkov. Sofia, p. 123-130. / Karaulov Yu.N. Yazykovoye soznanie kak protsess. Teoreticheskie predposylki odnogo eksperimenta. In Slovo. Yubileen sbornik, posveschen na 70-godishninata na prof. I. Chervenkova. Sofiya, s. 123-130 / Караулов Ю.Н. Языковое сознание как процесс. Теоретические предпосылки одного эксперимента. In Слово. Юбилеен сборник, посвещен на 70-годишнината на проф. И. Червенкова. София, с. 123-130.

Kedar, L. (1987). Power through discourse. Norwood: Ablex.

Knapp, M.L. \& Hall, J.A. (2002). Nonverbal communication in human interaction. Wadsworth: Thomson Learning.

Kobozeva, I.M. (2000). Grammar of space decription. In Logic analysis of language: languages of spaces. Arutyunova, N.D. \& Lyevontina, S.B. (eds.). Moscow: Yazyki slavianskoj kultury, p. 152-160. / Kobozeva I.M. Grammatika opisaniya prostranstva. In Logicheskij analiz yazyka: yazyki prostranstv. Arutyunova N.D., Lyevontina I.B. (red.). Moskva: Yazyki slavianskoj kultury, s. 152-160. / Кобозева И.М. Грамматика описания пространства. In Логический анализ языка: языки пространств. Арутюнова Н.Д., Левонтина И.Б. (ред.). Москва: Языки славянской культуры, с. 152-160.

Koubriakova, E.S. (2004). Language and knowledge: On the way to getting knowledge. Parts of speech from a cognitive perspective. The role of language in the world cognition. Moscow: Yazyki slavianskoj kultury. / Kubriakova E.S. Yazyk i znaniye: na 
puti polucheniya znanij o yazyke. Chasti rechi s kognitivnoj tochki zreniya. Rol' yazyka v poznaniyi mira. Moskva: Yazyki slavianskoj kultury. / Кубрякова Е.С. Язык $и$ знание: на пути получения знаний о языке. Части речи с когнитивной точки зрения. Роль языка в познании мира. Москва: Языки славянской культуры.

Kustova, G.I. (2000). The type of conceptualization of space and semantic features of the verb (the group the get). In Logic analysis of language: Languages of spaces. Arutyunova, N.D. \& Lyevontina, S.B. (eds.). Moscow: Yazyki slavianskoj kultury, p. 47-55. / Kustova G.I. Tip kontseptualizatsii prostranstva i semanticheskiye svojstva glagola (gruppa popast'). In Logicheskij analiz yazyka: yazyki prostranstv. Arutyunova N.D., Lyevontina I.B. (red.). Moskva: Yazyki slavianskoj kultury, s. 47-55. / Кустова Г.И. Тип концептуализации пространства и семантические свойства глагола (группа попасть). In Логический анализ языка: языки пространств. Арутюнова Н.Д., Левонтина И.Б. (ред.). Москва: Языки славянской культуры, с. 47-55.

Lakoff, G. (1987). Women, fire, and dangerous things. What categories reveal about the mind. Chicago; London: The University of Chicago Press.

Lander, E. \& Haegeman, L. (2016). The nanosyntax of spatial deixis. In Studia linguistica, 2 (1), p. 1-66. DOI: 10.1111/stul.12061

Langacker, R.W. (1987). Foundations of cognitive grammar. Vol. I. Theoretical prerequisites. Stanford: Stanford University Press.

Lebedeva, L.B. (2000). Semantics of the "limiting" words. In Logic analysis of language: Languages of spaces. Arutyunova, N.D., Lyevontina, S.B. (eds.). Moscow: Yazyki slavianskoj kultury, p. 93-105. / Lebedeva L.B. Semantika "ogranichivayuschikh" slov. In Logicheskij analiz yazyka: yazyki prostranstv. Arutyunova N.D., Lyevontina I.B. (red.). Moskva: Yazyki slavianskoj kultury, s. 93105. / Лебедева Л.Б. Семантика "ограничивающих" слов. In Логический анализ языка: языки пространств. Арутюнова, Н.Д., Левонтина, И.Б. (ред.). Москва: Языки славянской культуры, с. 93-105.

Levinson, S.C. \& Wilkins, D.P. (2006). Grammars of space. Explorations in cognitive diversity. New York: Cambridge University Press. 
Lin, H.-C. (2017). Image schemas: Meaning constructions on prepositions in phrasal verbs. In Book of abstracts. International cognitive linguistics conference: Linguistic diversity and cognitive linguistics, 10-14 July 2017, Tartu, Estonia, p. 349.

Lindner, S. (1983). A lexico-semantic analysis of verb-particle constructions with Up and Out. Indiana University Linguistics Club.

Lomtev, T.P. (1976). General and Russian linguistics. Selected texts. Moscow: Nauka. / Lomtev T.P. Obschee i russkoe yazykoznanie. Izbrannyie raboty. Moskva: Nauka. / Ломтев Т.П. Общее и русское языкознание. Избранные работы. Москва: Наука. Mac Laverty, B. (1984). Cal. London: Penguin Books.

Mandler, J.M. \& Canovas, C.P. (2014). On defining image schemas. In Language and cognition, 6 (4), p. 510-532. DOI: https://doi.org/10.1017/langcog.2014.14 Manerko, L.A. (2002). The conceptual model of discourse of space. In To language with love: a collection of research papers. Devoted to E.S. Koubriakova. Vinogradov, V.A. (ed.). Moskva-Voronezh: Voronezh state university, p. 398-412. / Manerko L.A. Kontseptualnaya model' prostranstvennogo diskursa. In $S$ lyubovyu $k$ yazyku: sbornik nauchnykh trudov. Posviaschaetsia E.S. Kubryakovoj. Vinogradov V.A. (red.). Moskva-Voronezh: Voronezhskij gosudarstvennyj universitet, s. 398-412. / Манерко Л.А. Концептуальная модель пространственного дискурса. In $C$ любовью к языку: сборник научных трудов. Посвящается Е.С. Кубряковой. Виноградов В.А. (ред.). Москва-Воронеж: Воронежский государственный университет, с. 398-412.

Manerko, L. (2016). Towards understanding of conceptualization in cognitive terminology. In Lege artis. Language yesterday, today, tomorrow. The journal of University of SS Cyril and Methodius in Trnava, I (2), December 2016, p. 129-170. DOI: 10.1515/lart-2016-0012 ISSN 2453-8035

McCullough, C. (1996). Tim. London: Pan Books.

McEwan, I. (1990). The innocent. London: Pan Books.

Mechkovskaya, N.B. (2004). Semiotics. Language. Nature. Culture. Moscow: Publishing house "Academia". / Mechkovskaya N.B. Semiotika. Yazyk. Priroda. 
Kultura. Moskva: Izdatelskij tsentr "Akademiya". / Мечковская Н.Б. Семиотика. Язык. Природа. Культура. Москва: Издательский центр "Академия".

Nijk, A.A. (2017). The historical present and representation spaces. In Book of abstracts. International cognitive linguistics conference: Linguistic diversity and cognitive linguistics, 10-14 July 2017, Tartu, Estonia, p. 145.

Orban-Lembrik, L.E. (2003). Social psychology [textbook for higher education establishments]. Kyiv: Academvydav. / Orban-Lembrik L.E. Sotsial'na psykholohiya [posibnyk dlya vuziv]. Kyyiv: Akademvydav. / Орбан-Лембрик Л.Е. Соиіальна психологія [посібник для вузів]. Київ: Академвидав.

Page, L. (1994). Peggie. London: Headline.

Palmer, F.R. (2004). The English verb. Available at:

https://books.google.com.ua/books?hl=ru\&lr=\&id=uf JAwAAQBAJ\&oi=fnd\&pg=P $\underline{\mathrm{T} 16 \& \mathrm{dq}=\mathrm{verbs}+\text { with }+ \text { postpositions }+\mathrm{in}+\text { english\&ots }=\mathrm{UWhZNXmpWm \& sig}=\mathrm{t} 5 \mathrm{RXk}}$ EY0PKTBHjr0Owm22ryeqOA\&redir esc $=\mathrm{y} \# \mathrm{v}=$ onepage \&q $=$ verbs $\% 20$ with $\% 20$ post positions $\% 20 \mathrm{in} \% 20$ english \&f=false

Pigalev, A.I. (1998). Space of culture. In Culturology: XX century. Dictionary. Levit, S.Ya. (ed.). Saint Petersburg: Universitetskaya kniga, p. 427-477. / Pigalev A.I. Prostranstvo kultury. In Kulturologiya: XX vek. Slovar'. Levit S.Ya. (red.). SanktPeterburg: Universitetskaya kniga, s. 427-477. / Пигалев А.И. Пространство культуры. In Культурология: ХX век. Словарь. Левит С.Я. (ред.). СанктПетербург: Университетская книга, с. 427-477.

Plungian, V.A. (2000). General morphology. Moscow: Editorial. / Plungyan V.A. Obschaya morfologiya. Moskva: Editorial. / Плунгян В.А. Общая морфология. Москва: Эдиториал.

Podlesskaya, V.I. (2000). "Face to face". In Logic analysis of language: Languages of spaces. Arutyunova, N.D. \& Lyevontina, S.B. (eds.). Moscow: Yazyki slavianskoj kultury, p. 98-107. / Podlesskaya V.I. "Litsom k litsu". In Logicheskij analiz yazyka: yazyki prostranstv. Arutyunova N.D., Lyevontina I.B. (red.). Moskva: Yazyki slavianskoj kultury, s. 98-107. / Подлесская В.И. "Лицом к лицу". In Логический 
анализ языка: языки пространств. Арутюнова Н.Д., Левонтина И.Б. (ред.). Москва: Языки славянской культуры, с. 98-107.

Privalova, I.V. (2005). Interculture and the verbal sign (linguo-cognitive basic concepts of intercultural communication). Moscow: Gnozis. / Privalova I.V. Interkultura $i$ verbalnyj znak (lingvokognitivnyye osnovy mezhkulturnoj kommunikatsii). Moskva: Gnozis. / Привалова И.В. Интеркультура и вербальный знак (лингвокогнитивные основы межкультурной коммуникации). Москва: Гнозис.

Radden, G. (1996). Motion metaphorized: the case of "coming" and "going". In Cognitive linguistics in the Redwoods: The expansion of a new paradigm in linguistics. Casad, H.E. (ed.). Berlin: Mouton de Gruyter, p. 423-458.

Rozhanskiy, F.I. (2000). The direction of motion (a typological research). In Logic analysis of language: Languages of spaces. Arutyunova, N.D. \& Lyevontina, S.B. (eds.). Moscow: Yazyki slavianskoj kultury, p. 56-66. / Rozhanskij F.I. Napravlenie dvizheniya (tipologicheskoe issledovanie). In Logicheskij analiz yazyka: yazyki prostranstv. Arutyunova N.D., Lyevontina I.B. (red.). Moskva: Yazyki slavianskoj kultury, s. 56-66. / Рожанский Ф.И. Направление движения (типологическое исследование). In Логический анализ языка: языки пространств. Арутюнова Н.Д., Левонтина И.Б. (ред.). Москва: Языки славянской культуры, с. 56-66.

Samedova, N. (2016). Verbs of locomotion like идти (to go) - ходить (to walk): some thoughts on their semantic description. In Lege artis. Language yesterday, today, tomorrow. The journal of University of SS Cyril and Methodius in Trnava, I (1), June 2016, p. 309-358. DOI: 10.1515/lart-2016-0007

Shaffer, B. \& Leeson, L. (2017). What I know is here; what I don't know is somewhere else: deixis and gesture spaces in American sign language and Irish sign language. In Book of abstracts. International cognitive linguistics conference: Linguistic diversity and cognitive linguistics, 10-14 July 2017, Tartu, Estonia, p. 126.

Soloschuk, L.V. (2006). Verbal and nonverbal components of communication in English discourse. Kharkiv: Constanta. / Soloschuk L.V. Verbal'ni i neverbal'ni komponenty komunikatsiyi $v$ anhlomovnomu dyskursi. Kharkiv: Konstanta/ 
Солощук Л. В. Вербальні і невербальні компоненти комунікаиї̈ в англомовному дискурсі. Харків: Константа.

Steel, D. (1998). The long road home. New York: A Dell Book.

Stefanowitsch, A. (2013). Variation and change in English path verbs and constructions: usage patterns and conceptual structure. In Variation and change in the encoding of motion events. Goschler, J. \& Stefanowitsch, A. (eds.). Amsterdam: John Benjamins, p. 223-244.

Talmy, L. (1985). Lexicalization patterns: semantic structure in lexical forms. In Language typology and syntactic description, 3, p. 57-149.

Taylor, J.R. (1995). On construing the world. In Language and the cognitive construal of the world. Taylor J.R. \& Mac Laury, R.E. (eds.). Berlin; New York: Mouton de Gruyter, p. 1-21.

Toporov, V.N. (1983). Space and text. In Text: semantics and structure. Moscow: Nauka, p. 135-164. / Toporov V.N. Prostranstvo i tekst. In Tekst: semantika i struktura. Moskva: Nauka, s. 135-163. / Топоров B.Н. Пространство и текст. In Текст: семантика и структура. Москва: Наука, с. 135-164.

Toshovich, B. (2000). Verbs of causation of location in space. In Logic analysis of language: languages of spaces. Arutyunova, N.D. \& Lyevontina, S.B. (eds.). Moscow: Yazyki slavianskoj kultury, p. 163-175. / Toshovich B. Glagoly kauzatsii polozheniya v prostranstve. In Logicheskij analiz yazyka: yazyki prostranstv. Arutyunova N.D., Lyevontina I.B. (red.). Moskva: Yazyki slavianskoj kultury, s. 163-175. / Тошович Б. Глаголы каузации положения в пространстве. In Логический анализ языка: языки пространств. Арутюнова Н.Д., Левонтина И.Б. (ред.). Москва: Языки славянской культуры, с. 163-175.

Trope, Y. \& Liberman, N. (2010). Construal-level theory of psychological distance. In Psychological review, 117 (2), p. 440-463.

Virotchenko, S.A. (2016). Peculiarities of negative emotions expression by nonverbal components (the gender aspect). In Messenger of V.N. Karazin Kharkiv National University, 84, p. 40-44. / Virotchenko S.A. Osoblyvosti vyrazhennya nehatyvnykh emotsij zasobamy neverbal'noyi komunikatsiyi (hendernyj aspekt). In Visnyk 
Kharkivs'koho natsional'noho universytetu imeni V.N. Karazina, 84, s. 40-44. I Віротченко С.А. Особливості вираження негативних емоцій засобами невербальної комунікації (гендерний аспект). In Вісник Харківського наџіонального університету імені В.Н. Каразіна, 84, с. 40-44.

Virotchenko, S.A. (2013). Peculiarities of functioning of the proxemic component in positive communication. In OMNES ET SINGULOS: language mediation in discourse [co]creation. Samokhina V.O. (ed.). Kharkiv: V.N. Karazin Kharkiv National University, p. 45-70. / Virotchenko S.A. Osoblyvosti funktsionuvannya proksemichnoj skladovoj v pozytyvno spryamovanomu spilkuvanni. In OMNES ET SINGULOS: poserednytstvo movy u dyskursyvnij [spiv] tvorchosti. Samokhina V.O. (red.). Kharkiv: Kharkivs'kyj natsional'nyj universytet imeni V.N. Karazina, s. 45-70. / Віротченко С.А. Особливості функціонування проксемічної складової в позитивно спрямованому спілкуванні. In OMNES ET SINGULOS: посереднищтво мови у дискурсивній [спів]творчості. Самохіна В.О. (ред.). Харків: Харківський національний університет імені В.Н. Каразіна, с. 45-70.

Vis, B.N. (2009). Built environments, constructed societies. Leiden.

Wendland, E.R. (2010). Framing the frames: a theoretical framework for the cognitive notion of "frames of reference". In Journal of translation, 6, p. 27-50.

\author{
Abbreviations \\ Adj - adjective \\ Cont - continuous \\ $\mathrm{G}-$ goal \\ Lim - limited \\ $\mathrm{N}-$ noun \\ Noncont - non-continuous \\ $\mathrm{O}-$ object \\ $\mathrm{P}-$ path \\ Postpos - postposition \\ Prep - preposition
}


$\mathrm{S}$ - source

Unlim - unlimited

$\mathrm{V}-$ verb

VCMS - verbal constructions of motion in space

Vmov - verb of movement

\begin{tabular}{|l|l|l|}
\hline \multicolumn{1}{|c|}{ Contact data } \\
$\begin{array}{l}\text { Svitlana A. Virotchenko } \\
\text { CSc. (Philology), } \\
\text { Associate Professor, Head } \\
\text { of the Department of } \\
\text { Oriental Languages and } \\
\text { Intercultural Communica- } \\
\text { tion, V.N. Karazin } \\
\text { Kharkiv National }\end{array}$ \\
$\begin{array}{l}\text { University, Svobody } \\
\text { Square 4, Kharkiv, 61022, }\end{array}$ \\
$\begin{array}{l}\text { Ukraine e-mail: } \\
\text { svetvir@gmail.com }\end{array}$
\end{tabular}

\section{Résumé in English}

The paper addresses the problem of conceptualization of communicative space in English. Space is a fundamental notion of human thinking that represents a diversified nature of the world's existence in its inhomogeneity; it is an environment of communicative activity and a necessary element of perceiving the world. Producing statements, communicants create communicative space. It consists of personal spaces of discursive personalities, which are the addresser's and addressee's ones that have a center and periphery with moveable boundaries. In a natural language, a mental representation of space is transformed into text. Studying the ways, in which motion in space is verbalized remains one of the topical issues of the present-day linguistic research. Yet, motion in the personal or communicative space is still in need of an indepth analysis. The research focuses on the image schematic structure of motion, which is actualized by verbal constructions of motion in space. Considering fragments that include expressions describing motion in the communicative space, I have revealed that the verbal constructions of motion in space actualize the source / path / goal schema 
with its binary oppositions (forward and back) and constituents, the part / whole schema by describing the whole-body or the part-body movement of the communicant, and the center / periphery schema that conceptualizes motion in space depending upon how far the communicant moves. I have also specified the structural constituents of the communicative space: the object of motion, the source, the goal and the path, and their syntactic occurrence in the sentence that can be fixed and implied. I have distinguished three classes of spatial references of the image schemas: anthropocentric, objective, and gravitational. The anthropocentric spatial references specify the direction of motion forward and back; the objective spatial references are mostly expressed by items of furniture (a table, a chair); the gravitational spatial references actualize motion influenced by gravitation - down and up. Thus, the cognitive oriented theory elaborated in the research sheds more light on the image schematic structure of motion in the communicative space and its actualization.

Keywords: addressee's / addresser's communicative space, image schema, motion in communicative space, verbal constructions of motion in space, verbalization.

\section{Résumé in German}

Der vorliegende wissenschaftliche Beitrag ist der Konzeptualisierung des kommunikativen Raumes des Englischen gewidmet. Der Raum gehört zu den grundlegenden Begriffen des menschlichen Denkens, der den vielseitigen Charakter der Weltexistenz schildert. Er wird als Milieu der kommunikativen Tätigkeit und eine unentbehrliche Komponente der Wahrnehmung der menschlichen Umwelt beschrieben. Bei der kommunikativen Interaktion schaffen die Kommunikanten einen kommunikativen Raum, der aus den individuellen Räumen der diskursiven Persönlichkeiten besteht. Diese werden als Adressaten- und Adressantenraum bezeichnet und haben ein Zentrum und eine Peripherie. In einer natürlichen Sprache wird eine mentale Vorstellung von dem Raum zu einem Text. Die Erforschung von Mitteln der Verbalisierung der räumlichen Bewegung gehört zu den aktuellen Fragen moderner Linguistik. Aber die Bewegung im persönlichen oder kommunikativen 
Raum braucht noch eine gründlichere Recherche. Im Mittelpunkt der vorliegenden Arbeit steht ein schematisches Modell der Bewegung, das durch verbale Konstruktionen der räumlichen Bewegung aktualisiert wird. Durch die Analyse der erwähnten Konstruktionen wurde festgestellt, dass dadurch folgende mentale Konstrukte aktualisiert werden: quelle / weg / ziel mit seinen binären Oppositionen (vorwärts und zurück) und Komponenten; teil / ganzes , das die Bewegung des ganzen Körpers des Kommunikanten bzw. eines seiner Körperteile beschreibt; zentrum / peripherie, das die Bewegung im Raum im Zusammenhang mit deren Weite zeigt. Außerdem wurden Strukturkomponenten des kommunikativen Sprachraums festgestellt: objekt der Bewegung, quelle, ziel und weg, sowie die Typen ihrer syntaktischen Repräsentation im Satz. Es wurden drei Klassen mentaler Schemen definiert, die als Raumorientierungspunkte dienen: antropozentrisch, objektorientiert und Gravitationsorientiert. Antropozentrische Orientierungsspunkte weisen auf die Richtung der Bewegung nach vorne oder nach hinten; objektorientierte Orientierungspunkte werden vorwiegend durch Möbelstücke (ein Tisch, ein Stuhl) dargestellt; Gravitationspunkte drücken die Bewegung nach unten und nach oben aus. Fazit: Die im Beitrag angeführte kognitiv orientierte Theorie erklärt die Struktur der Bewegung im kommunikativen Raum und seine Aktualisierung.

Stichwörter: Adressaten- und Adressantenraum, mentales Schema, Bewegung im kommunikativen Raum, verbale Konstruktionen der räumlichen Bewegung, Verbalisierung.

\section{Résumé in French}

L'article est consacré au problème de la conceptualisation de l'espace communicatif dans la langue anglaise. L'espace c'est le concept fondamental de la pensée humaine, qui reflète la nature multiforme de l'existence du monde; c'est le moyen d'activité communicative et la composante nécessaire de la perception du monde environnant. Réalisant l'interaction communicative, les communicants créent un espace communicatif composé des espaces personnels des personnalités discursives - adressé- 
communicatif et adressant-communicatif, qui possèdent le centre et la périphérie. Dans un langage naturel, l'image mentale de l'espace se transforme en un texte. L'éxamination des manières de la verbalisation du mouvement dans l'espace reste l'une des questions d'actualité des recherches linguistiques modernes. Dans le même temps, le mouvement dans un espace personnel ou communicatif a besoin d'une enquête plus approfondie. L'objet de cette recherche est un modèle schématique du mouvement, qui est actualisé par des constructions verbales du mouvement dans l'espace. En analysant les constructions verbales du mouvement dans l'espace, décrivant le mouvement dans l'espace communicatif, j'ai révélé qu'ils mettent à jour l'image source / voie / objectif avec ses oppositions binaires (avant et retour) et les composants partie / entier, décrivant le mouvement du corps entier ou une partie du corps du communicant, centre / périphérie, qui représente le mouvement dans l'espace, dépendant de la distance du mouvement du communicant. J'ai également établi les composantes structurelles de l'espace communicatif: l'objet du déplacement, la source, l'objectif et la voie, et aussi la fréquence et les types de leur représentation syntaxique dans la phrase. J'ai identifié les trois classes des points de la référence spatiaux des schémas d'image: anthropocentrique, objectif et gravitationnel. Points de référence spatiaux anthropocentriques indiquent la direction du déplacement en avant et en arrière; les indications substantielles sont principalement exprimées par les meubles (la table, la chaise); les indications gravitationnelles mettent à jour le mouvement vers le bas et vers le haut. Ainsi, la théorie cognitivement orientée, présentée dans cette article, clarifie le schéma-modèle du mouvement dans l'espace communicatif et son actualisation.

Mots-clés: l'espace adressé-communicatif / l'espace adressant-communicatif, l'imageschéma, le mouvement dans l'espace communicatif, les constructions verbales du mouvement dans l'espace, la verbalisation. 


\section{Résumé in Russian}

Статья посвящена проблеме концептуализации коммуникативного пространства в английском языке. Пространство - фундаментальное понятие человеческого мышления, которое отображает многогранный характер существования мира; это среда коммуникативной деятельности и необходимый компонент восприятия окружающего мира. Реализуя коммуникативное взаимодействие, коммуниканты создают коммуникативное пространство, состоящее из личных пространств дискурсивных личностей - адресатно-коммуникативного и адресантнокоммуникативного, которые имеют центр и периферию. В естественном языке ментальное представление о пространстве превращается в текст. Изучение способов вербализации перемещения в пространстве остается одним из актуальных вопросов современных лингвистических исследований. При этом движение в личном или коммуникативном пространстве нуждается в более глубоком исследовании. В фокусе внимания исследования - схематическая модель движения, которая актуализируется вербальными конструкциями движения в пространстве. В ходе анализа вербальных конструкций движения в пространстве, описывающих движение в коммуникативном пространстве, я выявила, что они актуализируют образ-схему источник / путь / цель с ее бинарными оппозициями (вперед и назад) и компонентами, часть / целое, описывая перемещение всего тела или части тела коммуниканта, центр / периферия, которая представляет движение в пространстве в зависимости от дальности перемещения коммуниканта. Я также установила структурные компоненты коммуникативного пространства: объект перемещения, источник, цель и путь, а также частотность и типы их синтаксической представленности в предложении. Я выявила три класса пространственных ориентиров образ-схем: антропоцентрические, предметные и гравитационные. Антропоцентрические пространственные ориентиры указывают на направление движения вперед и назад; предметные ориентиры в основном выражены предметами мебели (стол, стул); гравитационные ориентиры актуализируют движение вниз и вверх. Таким образом, когнитивно-ориентированная теория, представленная в статье, 
проясняет схематическую модель движения в коммуникативном пространстве и ее актуализацию.

Ключевые слова: адресатно- / адресантно-коммуникативное пространство, образ-схема, движение в коммуникативном пространстве, вербальные конструкции движения в пространстве, вербализация.

Article was received by the editorial board 16.06.17.

Reviewed 16.08.17. and 19.08.17.

Similarity Index 6\% 